\title{
PENGELOMPOKAN NEGARA DI DUNIA BERDASARKAN DATA RUNTUN WAKTU REALISASI PENANAMAN MODAL ASING DI INDONESIA MENGGUNAKAN ANALISIS CLUSTER
}

\author{
AFRIMAYANI, HAZMIRA YOZZA, DODI DEVIANTO \\ Program Studi S1 Matematika, \\ Fakultas Matematika dan Ilmu Pengetahuan Alam, Universitas Andalas, \\ Kampus UNAND Limau Manis Padang, Indonesia. \\ email : afrimayani1997@gmail.com
}

\begin{abstract}
Abstrak. Investasi sangat dibutuhkan di Indonesia. Perekonomian di Indonesia masih tertinggal dari negara-negara yang lain. Oleh karena itu, pemerintah perlu mencari sumber pembiayaan pembangunan ekonomi untuk mendorong pertumbuhan investasi, bukan hanya investasi dari dalam negeri namun juga investasi asing. Untuk melihat pola besarnya investasi asing di Indonesia, perlu dilakukan pengelompokan negara-negara. Pengelompokan tersebut diharapkan bisa membantu pemerintah dalam pengambilan kebijakan terkait investasi asing sesuai dengan negaranya. Analisis cluster merupakan suatu teknik analisis statistik dengan tujuan untuk memilah objek ke dalam beberapa cluster berdasarkan kesamaan-kesamaan objek atas dasar berbagai karakteristik. Penelitian ini bertujuan untuk membentuk cluster negara-negara di dunia berdasarkan data runtun waktu realisasi investasinya di Indonesia tahun 2000-2017. Teknik pengelompokan yang digunakan adalah analisis berhierarki dengan jarak euclidean. Hasil penelitian ini diperoleh sebanyak 2 cluster sebagai cluster optimum. Pada cluster 1 besarnya realisasi penanaman modal asing sepanjang tahun 2000-2017 cenderung hampir sama besar. Pada cluster 2 besarnya realisasi penanaman modal asing sepanjang tahun 2000-2017 lebih besar dibandingkan dengan cluster 1 dan mengalami perubahan yang signifikan.
\end{abstract}

Kata Kunci: Investasi Asing, Analisis Cluster Runtun Waktu, Jarak Euclidean

\section{Pendahuluan}

Penanaman modal (investasi) sangat dibutuhkan di setiap negara, demikian juga halnya dengan Indonesia. Perekonomian di Indonesia masih tertinggal dari negaranegara yang lain. Oleh karena itu, pemerintah perlu mencari sumber-sumber pembiayaan pembangunan ekonomi untuk mendorong pertumbuhan investasi. Indonesia sangat membutuhkan investasi, bukan hanya investasi dari dalam negeri namun juga investasi asing. Salah satu alasan utama mengapa Indonesia membutuhkan investor asing adalah daya konsumsi masyarakat serta tren ekspor yang masih rendah.

Pemerintah perlu mempertahankan strategi dalam menarik investor asing yang mendorong mereka untuk berinvestasi di sektor yang belum mampu diolah oleh pihak dalam negeri. Untuk melihat pola besarnya investasi asing di Indonesia, perlu 
dilakukan pengelompokan negara-negara. Pengelompokan tersebut diharapkan bisa membantu pemerintah dalam pengambilan kebijakan terkait investasi asing sesuai dengan negaranya. Dalam menentukan strategi untuk mengelompokkan negara asing, diperlukan analisis untuk mengelompokkan negara yang tepat. Dalam konsep statistik, suatu analisis yang digunakan untuk mengelompokkan objek adalah analisis cluster.

Analisis cluster merupakan suatu teknik analisis statistik dengan tujuan untuk memilah objek ke dalam beberapa cluster berdasarkan kesamaan-kesamaan objek atas dasar berbagai karakteristik [7]. Ukuran jarak yang digunakan adalah ukuran jarak euclidean. Selain itu, proses pengelompokan ini juga dibutuhkan metode perbaikan jarak yaitu metode pautan lengkap (complete linkage). Pada tulisan ini akan dilakukan pengelompokan negara-negara di dunia berdasarkan besar investasi yang ditanamkan di Indonesia dalam beberapa tahun menggunakan analisis cluster.

\section{Landasan Teori}

\subsection{Investasi}

Investasi merupakan bentuk penundaan konsumsi masa sekarang untuk memperoleh konsumsi di masa yang akan datang, dimana di dalamnya terkandung unsur risiko ketidakpastian sehingga dibutuhkan kompensasi atas penundaan tersebut [5]. Investasi ada dua macam, investasi dalam negeri dan investasi luar negeri (asing). Risk dan return merupakan prinsip utama dari investasi. Return adalah laba dari investasi sedangkan risk adalah kemungkinan mengalami kerugian dalam investasi. Pada umumnya hubungan antara return dan risk adalah linear. Umumnya, risiko yang lebih rendah diambil, keuntungan yang diperoleh lebih rendah dan sebaliknya. Prinsip-prinsip ini penting bagi investor sebelum membuat kesepakatan investasi [2]. Menurut UU No. 1 Th. 1967, yang dimaksud dengan "Penanaman Modal Asing adalah penanaman modal asing secara langsung yang dilakukan menurut atau berdasarkan ketentuan-ketentuan undang-undang ini dan yang digunakan untuk menjalankan perusahaan di Indonesia, dalam arti bahwa pemilik modal secara langsung menanggung risiko dari penanaman modal tersebut".

\subsection{Analisis Cluster}

Clustering adalah proses pengelompokan objek ke dalam kelas-kelas yang memiliki kesamaan. Clustering didasarkan pada kesamaan (similarity) atau ketaksamaan (dissimilarity) antar objek-objek. Satu-satunya cara untuk mengukur ketaksamaan adalah dengan suatu ukuran jarak (distance measure). Hasil dari proses clustering adalah cluster-cluster yang terdiri dari sekumpulan objek dengan kesamaan tertentu dalam satu cluster dan berbeda dengan objek yang berada pada cluster lain [7].

Ada dua metode cluster yaitu metode hierarki dan metode nonhierarki [6]. Metode hierarki diklasifikasikan ke dalam dua jenis yaitu Agglomerative (penyatuan) dan Divisive (pembagian). Perbedaan dari kedua metode ini bergantung pada komposisi hirarkis yang dilakukan, apakah dari bentuk bottom-up atau top-down. Metode yang digunakan pada penelitian ini adalah metode hierarki jenis agglomerative. Dalam metode hierarki, jarak masing-masing objek dihitung terhadap 
setiap objek yang lain. Selanjutnya, pasangan objek yang jaraknya terdekat digabung [7]. Tahap berikutnya dilakukan metode perbaikan jarak. Salah satu metode perbaikan jarak yang digunakan adalah metode pautan lengkap (complete linkage).

Metode pautan lengkap (complete linkage) didasarkan pada jarak maksimum. Jarak antara satu cluster dengan cluster yang lain diukur berdasarkan objek yang mempunyai jarak terjauh. Misalnya cluster $U$ dan $V$, untuk mendapatkan cluster $(U V)$. Jarak antara cluster $(U V)$ dan cluster lain $W$, dapat ditulis ke dalam rumus sebagai berikut [3]:

$$
d_{(U V) W}=\max \left\{d_{U W}, d_{V W}\right\},
$$

dimana $d_{U W}$ dan $d_{V W}$ merupakan jarak antara anggota cluster $U$ dengan cluster $W$ dan juga cluster $V$ dengan cluster $W$.

Prosedur tersebut dilakukan sampai diperoleh satu cluster yang memuat semua objek dan disajikan ke dalam bentuk dendogram. Dendogram disebut juga dengan grafik pohon, yaitu suatu alat grafis untuk menyajikan hasil dari analisis cluster yang dilakukan oleh peneliti dalam melakukan suatu penelitian. Dendogram berguna untuk menunjukkan anggota cluster yang ada jika akan ditentukan berapa banyak cluster yang seharusnya dibentuk.

\subsection{Data Runtun Waktu (Time Series)}

Data runtun waktu merupakan himpunan hasil observasi terhadap suatu variabel yang diambil secara beruntun atau terurut berdasarkan interval waktu yang tetap. Data runtun waktu adalah data yang dikumpulkan dari waktu ke waktu. Tujuannya adalah untuk menggambarkan perkembangan suatu kegiatan dari waktu ke waktu. Rangkaian data pengamatan runtun waktu dinyatakan dengan variabel $X_{t}$, dimana $t$ adalah indeks waktu dari urutan pengamatan [8].

\subsection{Analisis Cluster Data Runtun Waktu (Time Series)}

Definisi 2.1. [1] Analisis cluster data runtun waktu adalah suatu proses untuk mempartisi data runtun waktu $D=\left\{F_{1}, F_{2}, F_{3}, \cdots, F_{n}\right\}$ menjadi $C=$ $\left\{C_{1}, C_{2}, C_{3}, \cdots, C_{k}\right\}$ dalam suatu cara, sehingga data runtun waktu yang homogen akan dikelompokan bersamaan berdasarkan suatu ukuran kesamaan tertentu, maka $C_{i}$ sebagai cluster, dimana $D=\bigcup_{i=1}^{k} C_{i}$ dan $C_{i} \cap C_{j}=\emptyset$ untuk setiap $i \neq j$.

\subsubsection{Jarak Euclidean (Euclidean Distance)}

Adapun rumus jarak euclidean untuk dua data runtun waktu $u$ dan $v$ adalah sebagai berikut.

$$
d_{u v}=\sqrt{\sum_{t=1}^{n}\left(u_{t}-v_{t}\right)^{2}},
$$

dimana

$$
\begin{aligned}
n: & \text { Panjang data } u \text { dan data } v \\
d_{u v} & : \text { Jarak euclidean antara data runtun waktu } u \text { dan data runtun waktu } v .
\end{aligned}
$$




\subsection{Koefisien Silhouette}

Misal $n$ objek dapat dimasukkan sebanyak $k$ cluster. Batasan cluster yang dapat dibentuk adalah $k \leq n$, dengan $k=1$ dan $k=n$ dikecualikan, sehingga diperoleh $2 \leq k \leq(n-1)$. Koefisien silhouette yang digunakan untuk mengetahui kualitas pengelompokan atau pengukuran ketepatan pengelompokan dapat dirumuskan sebagai berikut [4].

$$
S(i)=\frac{b(i)-a(i)}{\max \{a(i), b(i)\}}
$$

dimana

$$
\begin{aligned}
i: & \text { objek yang akan diteliti, } \\
a(i): & \text { rata-rata jarak antar anggota dalam cluster, } \\
b(i): & \text { nilai minimum dari rata-rata jarak dari objek ke }-i \\
& \text { dengan objek yang berada di cluster lainnya, } \\
S(i): & \text { nilai koefisien silhouette pada objek ke }-i .
\end{aligned}
$$

\section{Identifikasi Masalah dan Data}

Negara-negara asing yang menanamkan modalnya di Indonesia berjumlah 17 negara yaitu Jerman, Swiss, Kanada, India, Belgia, Denmark, Italia, Perancis, Taiwan, Australia, Inggris, Belanda, Hongkong, USA, Jepang, Singapura dan Korea Selatan. Negara ini dipilih dengan pertimbangan kelengkapan data realisasi penanaman modal asing di Indonesia sepanjang tahun 2000-2017.

Langkah-langkah tahapan penelitian ini adalah melakukan analisis deskriptif untuk menggambarkan pergerakan investasi negara-negara asing di Indonesia, memperoleh matriks jarak euclidean, menggabungkan cluster yang memiliki jarak terdekat, melakukan perbaikan matriks jarak dengan metode complete linkage, mengulang langkah tersebut sebanyak $N-1$ kali, sehingga diperoleh satu cluster yang berisi semua objek, memilih jumlah cluster optimum yang terbentuk menggunakan kriteria koefisien silhouette dan melakukan interpretasi analisis cluster sesuai metode yang ditentukan.

\section{Pembahasan}

Data yang digunakan adalah data realisasi penanaman modal asing di Indonesia mulai dari tahun 2000 sampai tahun 2017. Kemudian dari data runtun waktu tersebut akan dilakukan pengelompokan negara-negara asing. Tahap awal yang harus dilakukan adalah menganalisis deskriptif untuk menggambarkan pergerakan investasi negara-negara asing di Indonesia. Berdasarkan data investasi asing tersebut diperoleh negara Jepang dan Singapura memiliki pola pergerakan dan besar realisasi investasi yang sangat berbeda dengan negara-negara yang lain. Sehingga dapat dikatakan bahwa kedua negara tersebut berbeda dari negara-negara lain dari segi realisasi modal yang ditanamkannya.

Diketahui jarak euclidean antara negara USA dengan negara Kanada adalah 4091.5703, sedangkan jarak Euclidean antara negara USA dengan negara Belgia 
adalah 4173.6744. Hal ini menunjukkan bahwa negara USA memiliki karakteristik yang lebih mirip dengan negara Kanada dibandingkan dengan negara USA dengan negara Belgia.

Penafsiran terhadap ukuran jarak antara negara-negara lain sama dengan yang diperlihatkan sebelumnya, dimana semakin kecil jarak yang diperoleh antara kedua objek, maka akan semakin mirip karakteristik dari kedua objek tersebut. Proses pengelompokan diawali dengan menganggap masing-masing objek sebagai satu cluster. Dengan demikian akan terdapat 17 cluster yang masing-masingnya terdiri dari satu negara. Dari 17 cluster tersebut terlebih dahulu dilihat cluster dengan jarak terdekat. Jarak antara negara Denmark (objek d) dan negara Italia (objek f) merupakan jarak yang terdekat sebesar 148,3478, sehingga kedua negara tersebut digabung menjadi satu cluster. Dengan demikian, akan terdapat 16 cluster.

Kemudian dari penggabungan dua cluster di atas dilakukan perbaikan jarak dengan menggunakan metode complete linkage, sehingga diperoleh matriks jarak baru. Perbaikan matriks jarak dilakukan dengan menggunakan metode complete linkage dari persamaan (2.1).

Dari hasil perbaikan jarak, diketahui bahwa jarak terdekat terjadi antara cluster $(d, f)$ dan $(c)$, sehingga pada tahap selanjutnya kedua cluster tersebut digabung. Selanjutnya dilakukan proses yang sama sampai diperoleh satu cluster yang berisi semua negara. Proses analisis cluster dapat diilustrasikan ke dalam bentuk dendogram. Berikut ini adalah dendogram pengelompokan negara di dunia berdasarkan data runtun waktu realisasi penanaman modal asing di Indonesia tahun 2000-2017:

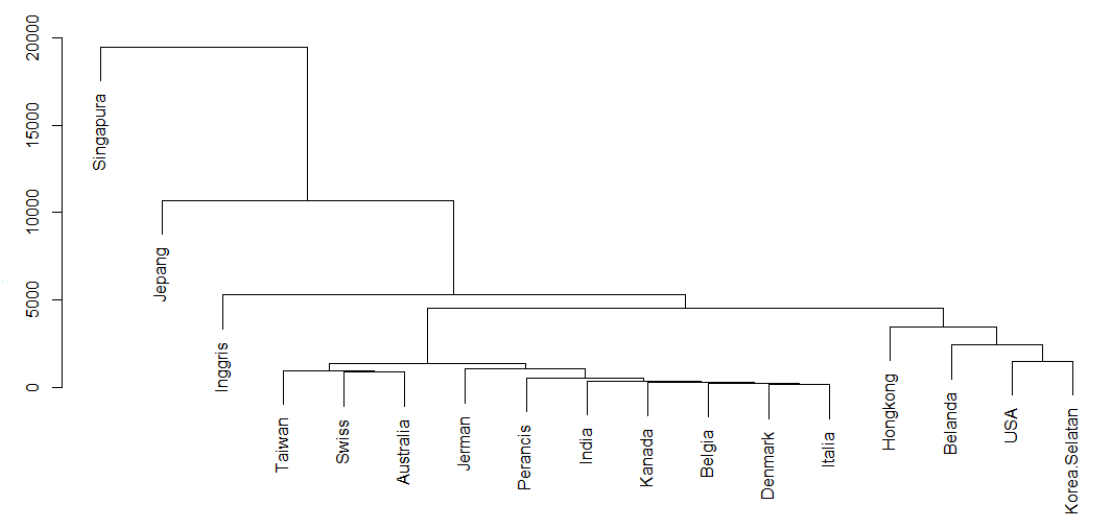

Gambar 1. Dendogram Analisis Cluster Hierarki pada Jarak Euclidean

Selanjutnya akan ditentukan banyak cluster optimum dengan perhitungan koefisien silhouette. Dengan koefisien tersebut banyak cluster optimum ditentukan berdasarkan nilai koefisien silhouette yang terbesar. Perhitungan silhouette hanya akan dilakukan untuk cluster sebanyak $k=2$ hingga $k=4$ cluster. Untuk menda- 
patkan nilai silhouette suatu $k$ tertentu, terlebih dahulu dihitung nilai silhouette untuk masing-masing negara berdasarkan pengelompokan yang terjadi. Berikut adalah perhitungan koefisien silhouette untuk negara USA (objek a) jika banyak cluster yang ditentukan $k=2$, yaitu:

$$
\begin{aligned}
a(a) & =\frac{d_{a, b}+d_{a, c}+\cdots+d_{a, q}}{15} \\
& =\frac{4091.5703+4173.6744+\cdots+3458.0713}{15}=3932.5040 \\
b(a) & =d_{a, o}=15829,9328,
\end{aligned}
$$

sehingga diperoleh nilai $S(a)$ adalah:

$$
\begin{aligned}
S(a) & =\frac{b(a)-a(a)}{\max \{a(a), b(a)\}} \\
& =\frac{15829.9328-3932.5040}{\max \{3932.5040,15829.9328\}} \\
& =0.7516
\end{aligned}
$$

Dari perhitungan diatas, diperoleh nilai koefisien silhouette pada negara USA untuk $k=2$ adalah 0.7516. Untuk memperoleh nilai koefisien silhouette pada masing-masing cluster yang terbentuk, dengan cara menghitung nilai rata-rata koefisien silhouette dari seluruh objek yang berada pada cluster yang sama. Hasil koefisien silhouette keseluruhan negara dapat dilihat pada Tabel 1.

Tabel 1. Koefisien Silhouette pada Jarak Euclidean

\begin{tabular}{|l|c|c|c|}
\hline Negara & $\mathbf{k = 2}$ & $\mathbf{k}=\mathbf{3}$ & $\mathbf{k = 4}$ \\
\hline USA & 0.7516 & 0.4778 & 0.2712 \\
\hline Kanada & 0.8718 & 0.8189 & 0.6840 \\
\hline Belgia & 0.8717 & 0.8188 & 0.6867 \\
\hline Denmark & 0.8685 & 0.8146 & 0.6732 \\
\hline Perancis & 0.8734 & 0.8202 & 0.6817 \\
\hline Italia & 0.8710 & 0.8187 & 0.6833 \\
\hline Belanda & 0.7619 & 0.5269 & 0.1213 \\
\hline Jerman & 0.8608 & 0.7924 & 0.5701 \\
\hline Inggris & 0.7040 & 0.4264 & 0 \\
\hline Swiss & 0.8708 & 0.8108 & 0.6659 \\
\hline Jepang & 0.1551 & 0 & 0 \\
\hline Korea Selatan & 0.7469 & 0.4459 & 0.1284 \\
\hline Hongkong & 0.7624 & 0.5496 & 0.3403 \\
\hline Taiwan & 0.8649 & 0.8012 & 0.6239 \\
\hline Singapura & 0 & 0 & 0 \\
\hline India & 0.8735 & 0.8213 & 0.6875 \\
\hline Australia & 0.8626 & 0.7918 & 0.5972 \\
\hline Rata-rata & $\mathbf{0 . 7 3 9 5}$ & $\mathbf{0 . 6 1 9 7}$ & $\mathbf{0 . 4 3 6 2}$ \\
\hline
\end{tabular}


Berdasarkan Tabel 1 dilihat bahwa semakin banyak jumlah cluster maka nilai koefisien silhouette semakin rendah. Hal tersebut mengindikasikan bahwa semakin banyak jumlah cluster yang terbentuk maka hasil pengelompokan menjadi kurang optimal. Dengan membentuk cluster sebanyak 2 diperoleh hasil koefisien silhouette dengan rata-rata 0.7395. Berdasarkan kriteria koefisien silhouette dapat dikatakan bahwa pengelompokan dengan membentuk 2 cluster pada jarak euclidean dapat dikategorikan adanya struktur cluster yang kuat. Berikut daftar anggota-anggota yang terbentuk sebanyak 2 cluster.

Tabel 2. Anggota dari Cluster yang Terbentuk dengan Jarak Euclidean

\begin{tabular}{|l|l|}
\hline Cluster & Anggota \\
\hline Cluster 1 & $\begin{array}{l}\text { USA, Kanada, Belgia, Denmark, Perancis, } \\
\text { Italia, Belanda, Jerman, Inggris, Swiss, Jepang, } \\
\text { Korea Selatan, Hongkong, Taiwan, India, Australia. }\end{array}$ \\
\hline Cluster 2 & Singapura \\
\hline
\end{tabular}

Selanjutnya akan dianalisis karakteristik investasi negara di setiap cluster yang terbentuk. Karakteristik cluster dilihat berdasarkan rata-rata investasi negara asing di Indonesia untuk setiap tahun, dari tahun 2000-2017 sehingga dapat dilihat pengelompokan negara yang besar investasinya memiliki kesamaan selama beberapa tahun tersebut. Pada Gambar 2 ditampilkan pola rata-rata investasi negara.

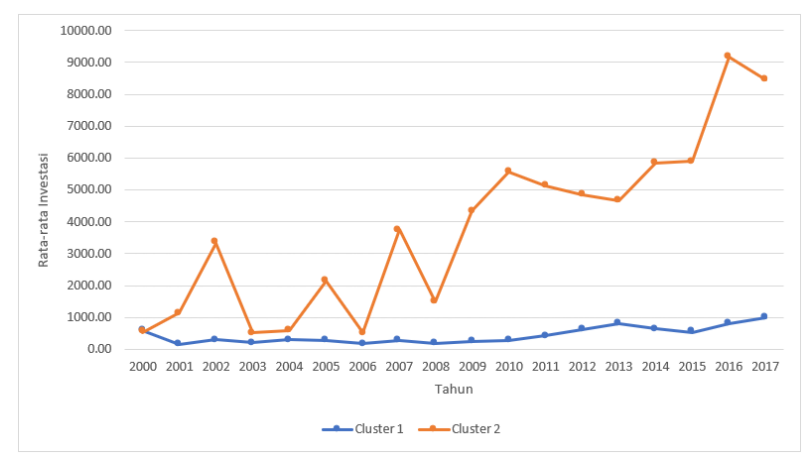

Gambar 2. Pola Investasi Negara pada Cluster 1 dan Cluster 2 Menggunakan Jarak Euclidean

Berdasarkan Gambar 2, terlihat bahwa cluster 1 memiliki pola pergerakan dan besar realisasi investasi yang sangat berbeda dengan cluster 2 . Untuk cluster 1 terlihat bahwa besarnya realisasi investasinya sepanjang tahun 2000-2017 berkisar antara 0-1000 juta dolar Amerika dan pergerakan besarnya investasi dari tahun ke tahun cenderung stabil atau tidak mengalami perubahan yang signifikan. Pada tahun 2013 rata-rata investasi meningkat, begitu juga dari tahun 2015 hingga tahun 2017 . 
Untuk cluster 2 memiliki bentuk grafik yang berbeda. Pada cluster 2 terlihat bahwa besarnya realisasi investasinya sepanjang tahun 2000-2017 berfluktuasi serta perubahannya sangat signifikan. Mulai tahun 2008 besarnya investasi tersebut cenderung meningkat sampai saat ini. Pada tahun 2011-2013 terjadi penurunan, namun naik drastis pada tahun selanjutnya, serta mengalami sedikit penurunan pada tahun 2017.

\section{Kesimpulan}

Berdasarkan teknik analisis data yang telah dilakukan diperoleh hasil pengelompokan negara asing sebanyak 2 cluster sebagai cluster optimum berdasarkan nilai koefisien silhouette. Hasil cluster pertama terdiri dari 16 negara yaitu Jerman, Swiss, Kanada, India, Belgia, Denmark, Italia, Perancis, Taiwan, Australia, Inggris, Belanda, Hongkong, USA, Jepang dan Korea Selatan. Hasil cluster kedua hanya terdiri dari 1 negara yaitu negara Singapura. Pada cluster 1 besarnya realisasi investasi asing sepanjang tahun 2000-2017 cendrung hampir sama besar. Pada cluster 2 besarnya realisasi investasi asing sepanjang tahun 2000-2017 lebih besar dibandingkan dengan cluster 1 .

\section{Ucapan Terima kasih}

Terimakasih kepada Izzati Rahmi HG, M.Si, Dr. Ferra Yanuar, dan Dr. Arrival Rince Putri yang telah memberikan kritik dan saran sehingga tulisan ini menjadi lebih baik.

\section{Daftar Pustaka}

[1] Aghabozorgi, S., A. S. Shirkhorshidi and T. Y. Wah. 2015. Time-series clustering, A decade review. Information Systems. 53: $16-38$

[2] Devianto, D. Maiyastri, and D.R. Fadhilla. 2015. Time series modeling for risk of stock price with value at risk computation. Applied Mathematical Sciences. 9(56): $2779-2780$

[3] Johnson, R.A. and D.W. Wichern. 1998. Applied Multivariate Statistical Analysis, Fourth Edition. Prentice Hall Inc, New Jersey

[4] Kaufman, L. dan Rousseeuw, P. J. 1990. Finding Groups in Data: An Introduction to Cluster Analysis. John Wiley, New York

[5] Martalena, M.Malinda. 2011. Pengantar Pasar Modal. Penerbit ANDI, Yogyakarta

[6] Rencher, A. C. 2002. Methods of Multivariate Analysis, Second Edition. WileyInterscience, United States of America

[7] Sartono, B. 2003. Analisis Peubah Ganda. IPB Press, Bogor

[8] Wei, W. W. S. 2006. Time Series Analysis: Univariate and Multivariate Methods, Second Edition. Addison Wesley, New York 